\title{
Recycling of textiles: the South African scene *
}

\section{Ment Larney and Annette M van Aardt}

\section{OPSOMMING}

' $n$ Versnelde ekonomiese groei en ontwikkeling in die nuwe politieke era wat Suid-Afrika nou betree, kan ' $n$ hernude aanslag op die omgewing beteken as gevolg van industriële afval. Hersiklering bied ' $n$ geleentheid om industriële en huishoudelike afval in bruikbare produkte te omskep. Die noodsaak vir die hersiklering van tekstielafval kan gemotiveer word deur die verhoogde kostes van grond vir en die vermindering in die beskikbaarheid van stortingsterreine, asook die uitputting van ons natuurlike grondstowwe wat andersins plaasvind.

Die doel van die studie was om vas te stel wat die huidige situasie ten opsigte van hersiklering in die tekstielbedryf is. Aspekte soos die volgende is onder andere ondersoek: Metodes van afvalwegdoening; hersikleringspraktyke; bereidwilligheid om te hersikleer en hersikleerde produkte te gebruik; persepsie ten opsigte van die haalbaarheid van so ' $n$ proses; struikelblokke ten opsigte van hersiklering en geskikte bemarkingstrategieë.

Die metode van ondersoek het die ontwikkeling en uitstuur van 'n gestruktureerde vraelys behels. Die vraelys is aan al die nywerhede wat aan die Tekstielfederasie behoort, uitgestuur.

Die resultate het aangedui dat verskeie afvalwegdoenpraktyke gevolg word. Die meeste tekstielvervaardigers verkoop hulle afval terwyl die helfte van die vervaardigers van hulle afval hersikleer. Die tekstielvervaardigers is redelik positief ten opsigte van hersiklering asook die gebruik van hersikleerde produkte in hulle produksie, met inagneming van die ekonomiese haalbaarheid daarvan. Volgens hulle is die belangrikste struikelblokke ten opsigte van hersiklering die gebrek aan toerusting en tegnologie, hersikleerde materiaal en 'n geskikte mark. Die meeste tekstielvervaardigers ondersteun ' $n$ bemarkingstrategie wat ' $n$ sterk handelsvraag na hersikleerde produkte skep en hulle beveel intensiewe advertering aan.

Daar is tot die gevolgtrekking gekom dat die verbruiker beter ingelig moet word ten opsigte van die aard en kwaliteit van hersikleerde produkte en dat die tekstielvervaardiger aangemoedig moet word om meer intensief te hersikleer.

\section{- Mrs M Larney \\ Consumer Sciences \\ Potchefstroom University \\ - Prof AM van Aadrdt \\ Consumer Sciences \\ Potchefstroom University}

With thanks to NRF for financial support for this study, which formed part of a master's degree

\section{INTRODUCTION}

In a previous article (Larney et al, 1996) a review was given of the recycling practices in the textile industry world-wide. Most of the reported recycling is happening in the US, but even for them it is not always economical or feasible, as explained by all the problems and barriers they have to overcome. The advantages of recycling, like reduction of waste, conservation of resources and savings on dumping sites have also been mentioned. Alarmingly, there is an indication that there might be a shortage of textiles in the near future, as well as an increase in prices. According to Chatterjee (1996) future cotton production in India is very uncertain and there isn't a constant growth curve. $\mathrm{He}$ points out that, due to the higher prices for raw materials and man-made fibres, it will be of utmost importance to recycle some of the waste. Linked to this, Carbone (1992) states that companies who want to stay in business have to be good environmentalists.

How does this situation reflect in South Africa? As far as is known, very little information on recycling, especially textile recycling in South Africa is published and it is difficult to obtain information on this practice. We do know that South Africa has a sound and responsible environmental policy (Larney et al, 1996) and cannot afford not to comply with the world's environmental regulations.

As South Africa is becoming part of the global world more and more it must comply with world-wide policies in reducing waste in a responsible way. South Africa has the potential to be a leader in this field in Africa if we take a look at what is happening at Sasol's polypropylene plant at Secunda. There they follow an integrated waste management system in that they have developed a cradle-to-grave methodology through which the entire process for a product is planned to be environmentally compatible (Monomer and polymer production: De-stigmatising the poor image of plastics, 1992).

Larney et al (1996) recommended that a study should be undertaken to assess the situation regarding the recycling of textiles in South Africa, a study that they undertook shortly afterwards. This study is reported in this article.

\section{OBJECTIVES}

The specific objectives of the study were to investigate the South African textile industries with regard to:

- disposal practices for solid waste

- recycling practices

- interest and willingness to recycle

- perception of quality of recycled products

- problems and barriers to enter the market for recycled products 
- marketing strategies required for recycled products.

\section{RESEARCH FRAMEWORK}

A research framework (Figure 1), based on frameworks used by Grasso (1995) and Domina and Koch (1997) to investigate textile-recycling practices, was designed to investigate various aspects of textile recycling in South Africa. The framework correlates with the objectives for this study.

The research framework and how these various aspects of recycling of solid waste in the South African textile industry were tested will subsequently be discussed. The authors would like to point out that they had published a literature review on this topic in this journal in 1996, so this discussion is kept concise in order to avoid repetition. Questions from the questionnaire investigating each component of the research framework are integrated in this discussion of the research framework.

\section{Solid waste disposal practices}

Domina and Koch (1997) point out that in the USA, textile manufacturers' solid waste exists of primary waste such as fibres, yarns and end-pieces of fabric while secondary waste includes yarn cones and packaging materials. According to Cedrone (1992) the two most important waste disposal practices in the USA are to sell it or to use it in landfills. There is, however, no doubt that recycling of textile waste is increasing in the USA, despite the fact that recycling costs still exceed the cost of landfill dumping (Berss, 1991). In a 1992 survey among 348 textile facilities in the US it was determined that $43 \%$ of their solid waste was recycled, while $39 \%$ was sent to landfills (Anderson, 1993). Ward (1995) reports that the main disposal routes in the UK are landfill and incineration through which 800000 tonnes of textile waste is disposed of annually, which could be considered a large resource loss. Various practices may be utilised to dispose of the solid textile waste in South Africa and these practices were investigated in this study by including questions in the questionnaire to determine whether manufacturers dump their waste in landfills, incinerate it, recycle it, sludge it, stockpile it or sell it. They were also asked whether they handle the disposal themselves or whether they contract it out.

\section{Recycling practices}

In the Concise Oxford Dictionary (1990) recycling is defined as the return of material to a previous stage of a cyclical process, with specific reference to the conversion of waste to a reusable material. Various ways and practices to achieve this are discussed in the literature (DREF2: Spinning wealth from waste, 1995; Textile waste processing lines, 1994; Brill, 1993). Items most frequently recycled include plastic bottles, bale packaging, polyester carpets, denim scraps and synthetic fibre waste (Grasso, 1995; Dahmen, 1993). Various methods are used in overseas countries to recycle textile waste into useful yarns and fabrics. Grasso (1995) points out that most recycling technology is new and proprietary and that little information is published to address the actual recycling process. In Germany, the Spindelfabrik Suessen developed a system by which parallel yarns can be spun after subjecting textile waste to tearing (Wirths, 1988). In Spain, a similar tearing process is used to recycle wool, jute, acrylic and polyester fabric waste into yarns (Textile waste processing lines, 1994). A popular textile fabric also sold in South Africa is Polartec, made

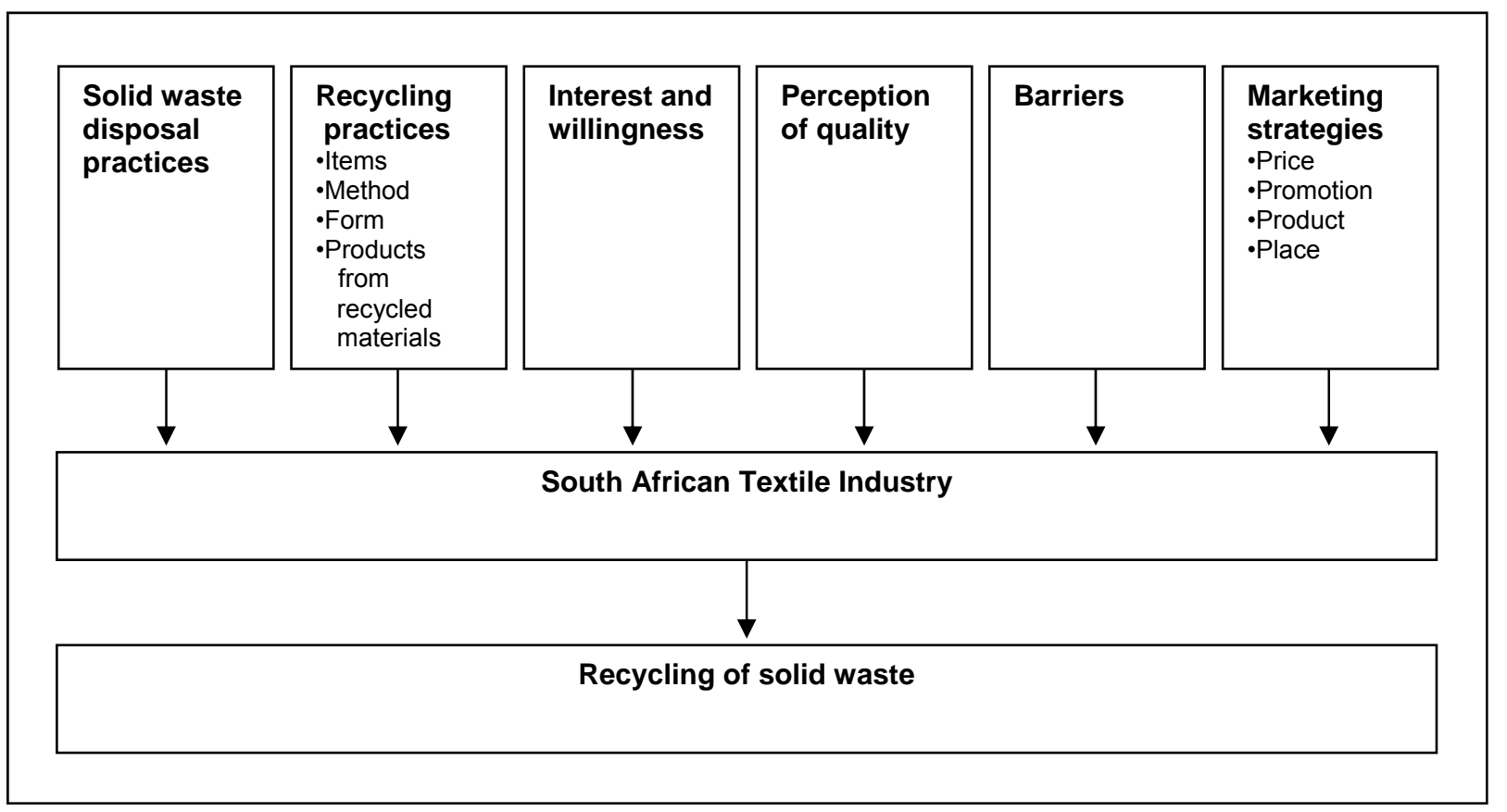

FIGURE 1: $\quad$ RESEARCH FRAMEWORK 
by Malden Mills in the USA from plastic beverage bottles which are chopped up, washed, dried, melted, and extruded in the form of fine filament yarns which are then crimped, cut up and spun into staple fibre and knitted. Polartec has a fleecy appearance and is often used for leisurewear (Diesenhouse, 1994). A similar fabric made from recycled plastic bottles is EcoSpun, made by Wellman (Rudie, 1994). Some manufacturers sell fabric waste in various forms. Various authors emphasise the importance of the sorting of waste and the fact that the waste should be in a good condition and free of foreign objects in order to ensure that waste is not viewed as garbage but rather as a valuable commodity (Dockery \& Kalogerides, 1993; Grasso, 1995). Grasso (1995) reports that those firms that sell their fabric waste are more likely to package it in boxes or in bales than to bag or bundle it. Products made from recycled fabric waste include non-wovens used for insulation, padding, upholstery, oil filters, hospital drapes and gowns, a variety of absorbent products like disposable wipes, geotextiles, carpets, fibrefill, spun-bonded fabrics from polyethylene and paper from denim scraps. Many other products such as trims from unravelled knits are also manufactured (Larney et al, 1996). In this study, the manufacturers were asked what they recycle, by whom the recycling is done, how they recycle and in what form it is sold in cases where they do sell the waste.

\section{Interest and willingness to recycle}

Many of the bigger textile manufacturers in the USA, England and other countries are starting to take an environmental awareness position in the market. In the UK a positive step by many companies is to set up an environmental management system to manage the environmental impact of industrial processes to be compatible with the best international standards. Dockery and Kalogeridis (1993) point out that interest and willingness to recycle textile waste is a stronger driving force than regulations or cost-saving initiatives. They report five environmental success stories that are all based on positive attitudes of manufacturers. One of these ingenious practices entails cotton waste being used for erosion control and as food for worms. Unfortunately, no matter how responsible the industries' actions may have become, the pragmatic question remains: "How much can we afford to do for the environment while maintaining our competitiveness?" (Abend, 1994). In the questionnaire, the manufacturers were asked whether recycling had a beneficiary value in their opinion, whether they would recycle textile products and whether economic feasibility was a condition for recycling.

\section{Perception of quality of products containing recy- cled raw materials}

Some authors point out that various manufacturers are of the opinion that products containing recycled raw materials are of an inferior quality and are afraid that some social stigma may be attached to recycled products (Grasso, 1995; Heeley, 1995), while others report that manufacturers perceive products contain- ing recycled raw materials as good quality (Dahmen, 1993; Kalogeridis, 1990; Ghosh \& Horrocks, 1995; Folk, 1994). It is clear that there is no unanimous attitude regarding quality of products containing recycled raw materials. In this study, manufacturers were asked how they perceived the quality of products containing recycled raw materials in comparison to that of products made from new materials.

\section{Barriers encountered by manufacturers}

There is plenty of evidence in the literature that textile manufacturers encounter various barriers to entering a recycling programme, such as a shortage of markets for recycled products, a lack of equipment and technology, high costs and competition with countries that do not participate in environmental practices. Recycling is a dynamic process and as markets become saturated with specific products such as wiping cloths and mop heads, new products have to be developed and introduced. Further, special equipment is needed, for instance, equipment necessary to shred fabrics, to separate waste and to extract fibres. A third and very important aspect is the cost of products as a barrier to entering the marketplace. Many of the processes are very labour-intensive, for example the sorting of waste. The economic feasibility of recycling is not yet proven (Grasso, 1995; Berss, 1991; Cedrone, 1992; Dahmen, 1993). In the questionnaire, South African manufacturers were asked to list the top three barriers to recycling of textile products and to entering the market place.

\section{Marketing strategies}

Carbone (1992) warns that companies wanting to stay in business have to be good environmentalists and have to follow effective strategies for recycling. Product, price, promotion and market place seem to be important issues in the marketing strategies. Larney (1998:112) points out that recycled products are in most cases not of inferior quality and therefore need not be cheaper than products made from new materials. Dahmen (1993) confirms the satisfactory and even high quality of recycled products. According to Grasso (1995) cooperative advertising, trade publication advertising and point-of-purchase promotion are the three most recommended types of trade promotion necessary for products made of recycled textiles. Products in which recycled materials are used currently, are discussed under recycling practices in this article. In addition, Grasso (1995) points out that recycled textiles are used in fabrics, home furnishings, fibres, yarns and rags. Regarding marketplace, more than half of the textile manufacturers in North Carolina support a marketing strategy that creates a strong trade or channel demand for use with products made from recycled textiles (Grasso, 1995). Larney et al (1996) are of the opinion that consumers should also be made aware of the importance of supporting recycling practices and should be encouraged to acquire a positive attitude towards buying these products. In the questionnaire, manufacturers were asked in which products they use recycled raw materials, how the price of products made from recycled raw materials 
should compare to that of products made from new materials, what level and type of promotion will be necessary and where and to whom marketing should be done.

\section{RESEARCH METHOD}

After a thorough literature study and discussion with representatives of the industry, a questionnaire was developed that addressed the purpose and objectives of the study.

\section{The instrument}

The questionnaire and mail survey relied mainly on the method described by Dillman (1978) and the individual questions correlated with the research framework. The content of each question is given at the end of the discussion of the respective components of the research framework. Most of the questions required a specific option, but several questions were openended, which allowed the respondent to give his own opinion on certain issues. Some questions allowed the respondent to select more than one option; therefore the responses to many questions do not total $100 \%$.

\section{The respondents}

An address list of all the textile manufacturers who are members of the Textile Federation was obtained. Not all textile manufacturers belong to the Textile Federation and a supplement of addresses was obtained from the Central Statistical Services. A questionnaire, accompanied by an introductory letter and a selfaddressed envelope, was mailed to 103 textile manufacturers at the end of 1996. At the beginning of 1997 the questionnaire was mailed a second and third time to those respondents who have not reacted to the first questionnaire. They were also telephonically reminded of the survey. The population of 103 textile manufacturers had to be adjusted due to companies no longer in business and those of which the addresses were incorrect. The adjusted population was 98 textile manufacturers. Thirty-four (Table 1) respondents $(35 \%)$, based on the adjusted population, returned the completed questionnaires.

In Table 2 a classification of the population in this study is given. For the purpose of this study, textile manufacturers were classified as companies which manufacture various kinds of yarns and fabrics from natural and/or man-made fibres, household textiles used for towels, blankets and carpets, knitted fabrics and auto-motive textiles, as well as all manufacturers who do preliminary processing like wool carding, and finishing processes like dyeing or scouring (CFSA, 1997:18).

The total percentage of respondents is more than $100 \%$ because some of the manufacturers could be classified under more than one product.

In Table 3 the respondents are classified according to size. Size of company was defined as the total num-
TABLE 1:

LOCATION OF TEXTILE MANU FACTURERS

\begin{tabular}{|l|c|r|}
\hline Province & N & \% \\
\hline Eastern Cape & 6 & 17,6 \\
\hline Western Cape & 9 & 26,5 \\
\hline Northern Cape & 0 & 0 \\
\hline Free State & 0 & 0 \\
\hline Kwazulu-Natal & 13 & 38,2 \\
\hline Mpumalanga & 1 & 2,9 \\
\hline Gauteng & 5 & 14,7 \\
\hline North West & 0 & 0 \\
\hline Limpopo & 0 & 0 \\
\hline Total & $\mathbf{3 4}$ & $\mathbf{1 0 0}$ \\
\hline
\end{tabular}

TABLE 2: CLASSIFICATION OF RESPONDENTS ACCORDING TO PRODUCT TYPE*

\begin{tabular}{|l|c|c|}
\hline Products & $\mathbf{N}$ & $\mathbf{\%}$ \\
\hline Woven cotton & 5 & 14,70 \\
\hline Woven woollens & 2 & 5,88 \\
\hline Woven man-mades & 13 & 38,24 \\
\hline Carpets and rugs & 1 & 2,94 \\
\hline Yarn & 10 & 29,41 \\
\hline Cordage and twine & 2 & 5,88 \\
\hline Non-woven fabrics & 8 & 23,53 \\
\hline $\begin{array}{l}\text { Textile goods not classified } \\
\text { elsewhere }\end{array}$ & 13 & 38,24 \\
\hline
\end{tabular}

Some manufacturers are classified under more than one type of product

ber of employees at the plant in 1997. Small-sized companies were those that employed 100 or fewer people; medium-sized companies employed more than 100 but fewer than 500 people; and large companies employed more than 500 people.

Due to the limited information on recycling in the textile industry, this was an exploratory study. Frequency tables are used to present most of the data. Both raw numbers ( $n$ ) and percentages (\%) are given. The total $\mathrm{N}$ varies between 26 and 34 .

For the Likert Scale-type questions, average values were calculated for each item in the question to be enabled to do a ranking for each statement. The items were scored as follows: positive statements $1=$ strongly disagree ( 1 point) to $5=$ strongly agree $(5$ points); negative statements $1=$ strongly disagree ( 5 points) to $5=$ strongly agree ( 1 point $)$.

In the questions where the respondents had the opportunity to circle all the responses that applied to them, each response was coded 1 if circled and 2 if left blank. This procedure permitted each response to be analysed as a separate question and each of these responses could be compared with the size or type of company. A Phi-coefficient $(\varnothing)$ indicates the relation- 
TABLE 3: $\quad$ NUMBER OF TEXTILE MANUFACTURERS ACCORDING TO SIZE

\begin{tabular}{|c|c|c|c|c|c|c|c|c|}
\hline \multicolumn{4}{|c|}{ Small } & \multicolumn{2}{c|}{ Medium } & \multicolumn{3}{c|}{ Large } \\
\hline $\begin{array}{c}\text { Number of } \\
\text { employees }\end{array}$ & $\mathbf{N}$ & $\mathbf{0}$ & $\begin{array}{c}\text { Number of } \\
\text { employees }\end{array}$ & $\mathbf{N}$ & $\mathbf{\%}$ & $\begin{array}{c}\text { Number of } \\
\text { employees }\end{array}$ & $\mathbf{N}$ & $\%$ \\
\hline $1-20$ & 0 & 0 & $101-200$ & 11 & 33,4 & $501-1000$ & 6 & 18,2 \\
\hline $21-50$ & 1 & 3 & $201-500$ & 4 & 12,1 & $1001-3000$ & 9 & 27,3 \\
\hline $51-100$ & 2 & 6 & & & & $3001-5000$ & 0 & 0 \\
\hline & $\mathbf{3}$ & $\mathbf{9}$ & & $\mathbf{1 5}$ & $\mathbf{4 5 , 5}$ & & $\mathbf{1 5}$ & $\mathbf{4 5 , 5}$ \\
\hline
\end{tabular}

TABLE 4: $\quad$ SOLID WASTE DISPOSAL PRACTICES

\begin{tabular}{|l|c|c|c|c|}
\hline \multirow{2}{*}{ Practices } & \multicolumn{2}{|c|}{ Do it themselves } & \multicolumn{2}{c|}{ Have it done } \\
\cline { 2 - 5 } & $\mathbf{N}$ & $\mathbf{N}$ & $\mathbf{N}$ & 29,4 \\
\hline Landfill & 4 & 11,8 & 0 & 0 \\
\hline Incinerate & 3 & 8,8 & 4 & 11,8 \\
\hline Recycle & 12 & 35,3 & 3 & 8,8 \\
\hline Sludge & 0 & 0 & 0 & 0 \\
\hline Stockpile & 0 & 0 & 20 & 58,8 \\
\hline Sell it & 0 & 0 & & \\
\hline
\end{tabular}

ship between the size and type of company and the response. It was calculated by determining square root of the chi square value divided by $\mathrm{N}$ (the number of respondents) (Cohen, 1988:223). Cohen gives directives for interpreting these values. $\varnothing=0,1$ indicates a small effect, $\varnothing=0,3$ indicates a medium effect and $\varnothing=0,5$ a large effect. Effect sizes $\geq 0,5$ indicate a large practically significant relationship.

\section{RELIABILITY AND VALIDITY}

\section{Reliability}

Because this was an exploratory study, reliability could not be determined by means of the most commonly used methods like the test/retest method (De Wet et al, 1981:131). The questionnaire was tested on three representatives of the textile industry. This was done to point out any obscurity in the questionnaire. According to Mouton and Marais (1989:79) reliability is determined by four variables, namely data collection technique, the influence of the researcher, the respondent and the research circumstances. The researcher took all possible measures to comply with these given guidelines to ensure the collection of reliable data.

\section{Validity}

Validity in this study can be evaluated in terms of content validity, which reflects the extent to which the questionnaire measures what it is supposed to measure (Babbie, 1995:128; Murphy \& Davidshover, 1994:108). In this study, the procedure by Murphy and Davidshover (1994:111) for assessing content validity, which consists of three steps, was followed. First, a literature study was undertaken to describe the content domain, upon which the researchers verified each test item to ensure that it represented an area of the content domain and that all the content domain areas were represented in the questionnaire. Lastly, the structure of the questionnaire was compared with the structure of the content domain. In this study the research framework represents the latter.

\section{RESULTS AND DISCUSSION}

The results are presented according to the research framework and the questions in the questionnaire.

\section{Solid waste disposal practices}

Various solid waste disposal practices and the extent to which manufacturers participate in these as well as the way in which they do it are given in Table 4.

Some textile manufacturers follow more than one disposal practice. The waste of more than half of the manufacturers is lost by dumping, incinerating and/or sludging, which are done by them or other instances. The waste of $16(47 \%)$ of the manufacturers is recycled, either by themselves $(12 / 35,3 \%)$ or by other companies $(4 / 11,8 \%)$. The trend that equal amounts of waste are sold and lost through dumping, incinerating or sludging while less is recycled is to an extent in accord with practices in the United States (Domina \& Koch, 1997; Anderson, 1993). Dumping is not a desirable practice, as it does not save on resources and landfills are dwindling.

To determine whether companies' willingness to recycle their waste is related to their size, a phi-coefficient was computed to determine the relationship between recycling practices and the size of the company. A phi-coefficient of 0,482 was found, indicating a large practically significant relationship between the sizes of the companies and their recycling practices. Twelve 
of the medium to large-sized companies recycle their waste, while none of the small companies recycle, probably because the latter do not have facilities to recycle their waste themselves. These findings are in accordande with those of Grasso (1995), who points out that the larger the volume of waste produced, the greater the need to dispose of the waste. In addition, larger companies usually have more resources for acquiring technology to process the waste internally.

\section{Recycling practices}

Apart from the expected fibre, yarn and fabric waste, textile manufacturers in addition generate solid waste from items such as yarn cones and packaging materials. The percentages of companies that recycle certain waste items are, in descending order, cardboard boxes $(75 \%)$, paper waste $(57,6 \%)$, packaging materials and yarn cones and tubes (48,5\% each), yarn and textile waste $(45,5 \%$ each), fibre waste $(33,3 \%)$ and baling wire and pallets $(27,3 \%$ each). The most frequently recycled products are paper-based items which are easy to recycle and for which there is a big demand. This corresponds with the findings of studies by Dockery and Kalogeridis (1993) and the Hartman Group (1994).

Those companies that recycle their fibre, yarn and fabric waste use more than one recycling practice. Of those responding $(n=34)$, in descending order report as follows: $44,1 \%$ sell their waste to another manufacturer that uses the waste in its production, 35,3\% process their waste further within their own company, $23,5 \%$ sell their waste to another company that specializes in recycling while $2,9 \%$ donate their waste to charity. The fact that only a third of the responding companies process their waste internally points to a need for a paradigm shift regarding the recycling of textile waste.

The companies that sell their fibre, yarn and textile waste $(\mathrm{N}=23)$ can sell it either as sorted or unsorted combined waste in different packaging forms. Table 5 depicts the percentage of companies that sell waste in the various forms.

The results show that bags and cardboard boxes are the most popular packaging forms and $20(87 \%)$ of those companies that sell their waste sort it before selling. The latter obviously value their waste and see it as a useful commodity for other manufacturers (recyclers) to whom it is important to buy debris-free waste in sorted form (Domina \& Koch, 1997; Dockery \& Kalogeridis, 1993).

\section{Interest and willingness of companies towards recycling}

To determine the textile manufacturers' interest in and willingness to produce or use recycled products, the respondents were asked to what degree they complied with the statements in Table 6.

Regarding the first three statements, it is clear that the respondents have a positive approach towards recy-
TABLE 5:

PACKAGING FORMS IN WHICH TEXTILE WASTE IS SOLD*

\begin{tabular}{|l|c|c|c|c|}
\hline \multirow{2}{*}{ Packaging forms } & \multicolumn{2}{|c|}{ Sorted } & \multicolumn{2}{c|}{ All combined } \\
\cline { 2 - 5 } & $\mathbf{N}$ & $\%$ & $\mathbf{N}$ & $\%$ \\
\hline In bags & 8 & 34,8 & 5 & 21,7 \\
\hline $\begin{array}{l}\text { In cardboard } \\
\text { boxes }\end{array}$ & 6 & 26,1 & 3 & 13,0 \\
\hline In bales & 3 & 13,0 & 2 & 8,7 \\
\hline In bundles & 3 & 13,0 & 0 & 0 \\
\hline
\end{tabular}

* Companies could sell waste in more than one form

cling since for all three statements 24 respondents either agreed or definitely agreed that they would recycle or use recycled products. Regarding the economic viability of using recycled fibres in new textile products, the respondents were less convinced that it was a good proposition, since nearly equal numbers of respondents were positive and negative towards this issue, and in case of statements 4-6 a relatively large number of respondents chose the middle response category, indicating some hesitation regarding the economic viability. Responses regarding the potential liability of recycled products (statement 7 ) indicated that most of the companies did not experience this as a major problem. The majority of the respondents were either unsure or convinced that specific marketing strategies (statements 8 and 9) such as these creating a strong end consumer or a strong pipeline demand would be required and that a new target market may be attracted (statement 10). Grasso (1995) found that $76 \%$ of the companies in her study were willing to produce products using recycled materials if it was economically feasible. When looking at the ranking order of the scores in Table 6 , it is clear that the scores of the positive statements 1-3, that also reflect a more personal viewpoint, were ranked the highest, followed by the statements concerned with specific required marketing strategies. Negative statement 5 , concerned with the high cost of recycling for companies, ranked lowest among the average scores.

Overall perception of quality of products of recycled materials and relation thereof to the size of companies

The perceptions regarding this aspect are reflected in Table 7.

In the overall group of manufacturers all of them were of the opinion that the quality of products of recycled materials was lower than the quality of products made using new materials. In a similar study by Grasso (1995) respondents also reflected this opinion. When comparing the opinions of manufacturers from small, medium and large companies, results in Table 7 show that all the manufacturers in small companies esteemed the quality of products of recycled materials lower than that of products made using new materials, while $75 \%$ of manufacturers from medium-sized com- 
TABLE 6:

INTEREST AND WILLINGNESS OF COMPANIES TOWARDS RECYCLING

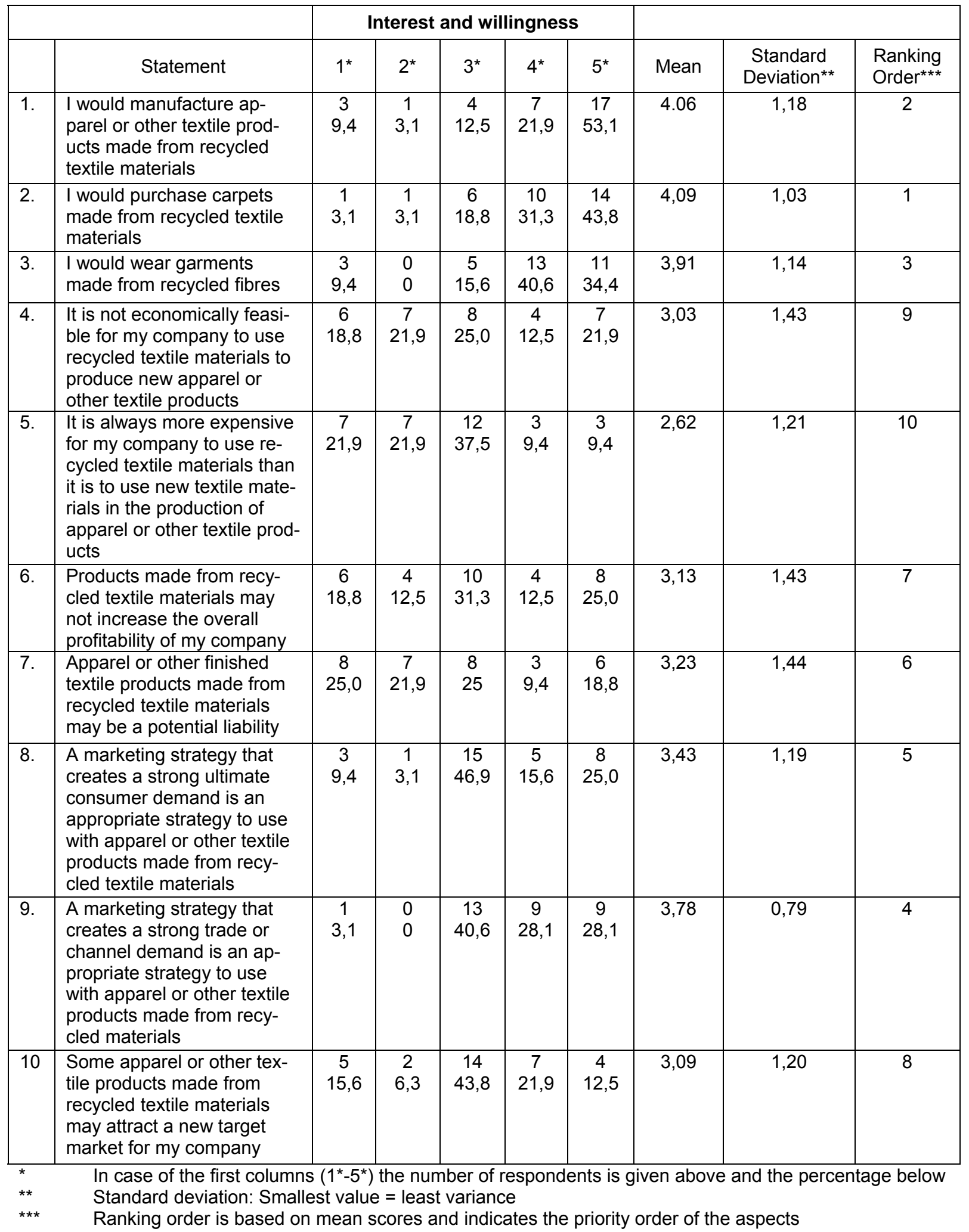


TABLE 7:

OVERALL PERCEPTION OF QUALITY OF PRODUCTS OF RECYCLED MATERIALS AND RELATION TO THE SIZE OF COMPANIES

\begin{tabular}{|c|c|c|c|c|c|c|c|c|}
\hline \multirow{3}{*}{$\begin{array}{l}\text { Quality of recycled } \\
\text { products }\end{array}$} & \multirow{2}{*}{\multicolumn{2}{|c|}{ Overall perception }} & \multicolumn{6}{|c|}{ Size of manufacturers } \\
\hline & & & \multicolumn{2}{|c|}{$\begin{array}{c}\text { Small } \\
(1-100)\end{array}$} & \multicolumn{2}{|c|}{$\begin{array}{c}\text { Medium } \\
(101-500)\end{array}$} & \multicolumn{2}{|c|}{$\begin{array}{l}\text { Large } \\
(>500)\end{array}$} \\
\hline & $\mathbf{N}$ & $\%$ & $\mathbf{N}$ & $\%$ & $\mathbf{N}$ & $\%$ & $\mathbf{N}$ & $\%$ \\
\hline $\begin{array}{l}\text { Significantly lower } \\
\text { quality }\end{array}$ & 11 & 40,7 & 1 & 50 & 5 & 41,7 & 5 & 38,5 \\
\hline Slightly lower quality & 8 & 29,6 & 1 & 50 & 4 & 33,3 & 3 & 23 \\
\hline No difference in quality & 4 & 14,8 & 0 & 0 & 0 & 0 & 4 & 30,8 \\
\hline Slightly higher quality & 0 & 0 & 0 & 0 & 0 & 0 & 0 & 0 \\
\hline $\begin{array}{l}\text { Significantly higher } \\
\text { quality }\end{array}$ & 0 & 0 & 0 & 0 & 0 & 0 & 0 & 0 \\
\hline Not sure & 4 & 14,8 & 0 & 0 & 3 & 25 & 1 & 7,7 \\
\hline Total & 27 & 100 & 2 & 100 & 12 & 100 & 13 & 100 \\
\hline
\end{tabular}

panies and $61,54 \%$ of manufacturers from large companies were of the same opinion.

From the results it can be deduced that manufacturers from larger companies are less negative towards the quality of products made from recycled materials. That this opinion is probably biased is obvious when studying scientific factual literature on the quality of products containing recycled materials. Dahmen (1993), Kalogeridis (1990) and Alper and Spalding (1985) all confirm that textile products made from recycled materials are in no way inferior in quality to products made using new materials.

Significant barriers that manufacturers encounter in manufacturing and marketing of recycled products

Respondents were asked to rank the barriers in manufacturing and marketing of recycled products as most significant, second most and least significant.

According to Table 8 , in the response category of most significant barriers, $20,6 \%$ of the respondents chose lack of recycled raw material followed by $17,6 \%$ who chose lack of equipment to process the recycled material and two equal groups of $11,8 \%$ who chose lack of market and lack of technology as most significant barriers. In the category of second most significant barriers $17,6 \%$ chose lack of technology, while $14,7 \%$ chose lack of equipment to process the recycled material. In the category of third most significant barriers, equal groups of $14,7 \%$ chose lack of market and cost of recycled products. Three groups of $8,8 \%$ chose lack of equipment to process the recycled material, lack of recycled raw material and lack of awareness of the immediate consumers. In Grasso's study (1995) lack of market was ranked as the most significant barrier, followed by lack of equipment to process the recycled material as second most significant barrier and cost of product as least significant barrier.

Desirable marketing strategies with reference to recycled textile products
In order to plan marketing strategies effectively, aspects regarding the product, price, promotion and market place should be considered (Ferrell et al, 2002:10). The manufacturers were asked to supply information regarding these aspects with reference to textile recycling practices in South Africa.

Regarding products they were requested to list the products (fibre, yarn or fabric) which were recycled by their factories and in which products these recycled materials were used. The respondents indicated that yarn was the most common recycled textile material, as three fibre recyclers, five yarn recyclers and three fabric recyclers recycled their textile materials. One of the reasons for this could be that no special equipment is required for the spinning of recycled yarn. One of the most popular products made from recycled fibre and fabric is filling material for duvets and pillows. Other products made from recycled textile materials are medical products, polyester for industrial use and carpet underlay. The type of textile products made from recycled textile products in South Africa correspond with those made in the USA, as can be seen from Grasso's study (1995).

With reference to the price of recycled products, many consumers have the perception that products made from recycled material are inferior in quality (a perception which has already been proved false) and therefore have to be cheaper. Among the manufacturers, more than three-quarters were of the opinion that products made from recycled fibres should be low to moderate in price.

According to the manufacturers, the level of promotion required for the marketing of products made from recycled fibres should be more or less the same (36\%) or a little to considerably higher (36\%). Only $28 \%$ were of the opinion that a lower level of promotion could be maintained. The types of promotion for products made from recycled textile materials as recommended by the manufacturers were advertising in trade journals $(32,4 \%)$, cooperative advertising $(29,4 \%)$, direct sales $(29,4 \%)$, point of purchase promotion $(23,5 \%)$ and trade shows $(23,5 \%)$. The priority order differs 
TABLE 8:

SIGNIFICANT BARRIERS THAT MANUFACTURERS ENCOUNTER IN MANUFACTURING AND MARKETING OF RECYCLED PRODUCTS

\begin{tabular}{|l|c|c|c|c|c|c|}
\hline & \multicolumn{2}{|c|}{ Most significant barrier } & \multicolumn{2}{c|}{$\begin{array}{c}\text { Second most } \\
\text { significant barrier }\end{array}$} & \multicolumn{2}{c|}{$\begin{array}{c}\text { Third most } \\
\text { significant barrier }\end{array}$} \\
\hline & $\mathbf{N}$ & $\%$ & $\mathbf{N}$ & $\%$ & $\mathbf{N}$ & $\%$ \\
\hline Lack of market & 4 & 11,8 & 4 & 11,8 & 5 & 14,7 \\
\hline Lack of technology & 4 & 11,8 & 6 & 17,6 & 2 & 5,9 \\
\hline $\begin{array}{l}\text { Lack of equipment to process the } \\
\text { recycled material }\end{array}$ & 6 & 17,6 & 5 & 14,7 & 3 & 8,8 \\
\hline Cost of product & 3 & 8,8 & 2 & 5,9 & 5 & 14,7 \\
\hline Cost of promotion & 0 & 0 & 1 & 2,9 & 0 & 0 \\
\hline $\begin{array}{l}\text { Lack of your immediate consumers' } \\
\text { awareness }\end{array}$ & 2 & 5,9 & 3 & 8,8 & 3 & 8,8 \\
\hline Lack of ultimate consumers' awareness & 3 & 8,9 & 0 & 0 & 2 & 5,9 \\
\hline Lack of recycled raw material & 7 & 20,6 & 1 & 2,9 & 3 & 8,8 \\
\hline Liability & 1 & 2,9 & 2 & 5,9 & 0 & 0 \\
\hline Health risks & 1 & 2,9 & 1 & 2,9 & 0 & 0 \\
\hline Recycled products are of low quality & 2 & 5,9 & 0 & 0 & 1 & 2,9 \\
\hline
\end{tabular}

slightly from the findings in the study of Grasso (1995), where cooperative advertising, tradepublication advertising and point-of-purchase promotion were the three most recommended types of promotion.

With respect to where and to whom marketing should be done, most of the respondents $(46,9 \%)$ were not sure whether a marketing strategy that created a strong ultimate consumer demand was an appropriate strategy to use with apparel or other textile products made from recycled textile materials, while $40,4 \%$ agreed that this strategy would be appropriate. Most of the respondents $(54,2 \%)$ agreed that a marketing strategy creating a strong trade or channel demand would be an appropriate strategy to use for products made from recycled materials, while $40,6 \%$ were not sure whether this strategy would be appropriate for marketing products made from recycled materials.

\section{CONCLUSIONS AND RECOMMENDATIONS}

Textile industries world-wide are inclined to recycle only in cases where it is economically feasible. This seems to be the case in South Africa as well, but companies that can afford it should be encouraged to recycle even if it is not economically feasible for the sake of the environmental impact. Solid waste is disposed of in several ways, but it is encouraging that nearly half of the manufacturers do recycle or have their waste recycled, while most of the companies sell their waste. Of those who sell their waste, a large percentage sort it beforehand, which is advisable, because downstream to the recycler, the waste will then not be viewed as "garbage", but rather will be valued as a commodity, as it will be debris free and the recycler will be able to process it more efficiently and economically.
About a third of the manufacturers recycle their waste themselves, of which all are large of medium-sized companies. More research is necessary to determine what specific barriers smaller companies encounter in recycling. Packaging materials are mostly recycled, although some textile waste is also recycled. Most of the recycling companies convert their waste into yarn, probably due to available facilities and because it is the most feasible product. The majority of the companies indicated their willingness to recycle or to use recycled products. They were, however, hesitant about the economic feasibility of recycling or using recycled products in manufacturing. They were largely of the opinion that specific marketing strategies would be necessary to create a greater demand for recycled products. Nearly all the companies were of the opinion that products made from recycled materials would be of lower quality than those made from new materials. Smaller companies were even more negative than larger companies about the quality, probably because they don't practice recycling. It is recommended that this biased opinion regarding the lower quality of textile products made from recycled materials be addressed by distributing scientific, factual and recent information on the quality of recycled materials, by authoritative bodies such as the Textile Federation, for instance through newsletters. In review of the responses regarding significant barriers that manufacturers encounter in manufacturing and marketing of recycled products, it seems that technological factors in South Africa hamper recycling most significantly while marketing factors seem to be the least significant barriers. One of the reasons for the technological barriers could be that due to sanctions against South Africa, technological development in textile manufacturing fell behind. The manufacturers obviously felt that the lack of market for recycled textile materials and products necessitated a specific promotional effort, concentrating on trade journal advertising and co-operative advertising, which may strengthen consumer demand and ultimately the mar- 
ket. Appropriate marketing strategies (where and to whom marketing should be done) seemed to be a point of uncertainty. One explanation for this uncertainty of market potential could be the economic barriers, as textile recycling is in general not cost-effective at present. Most respondents agreed that a marketing strategy creating a strong trade or channel demand would be advisable, probably because the industry would then be moved forward.

\section{REFERENCES}

ABEND, J. 1994. The green wave swells. Bobbin 35 (3):92-98.

ALPER, J \& SPALDING, BJ. 1985. Synthetic ivory from recycled fibres. Chemical World September:2324.

ANDERSON, DE. 1993. U.S. textile mills recycle almost half of waste. Textile news/information August:1-3.

BABBIE, E. 1995. The practice of social research. $7^{\text {th }}$ ed. New York. Wadsworth.

BERSS, M. 1991. No one wants to shoot Snow White. Forbes October:40-42.

BRILL, B. 1993. Textile recycling fact sheet. Council for Textile Recycling. Bethesda, MD.

CARBONE, A. 1992. Industry and the environment: Making business part of the solution. USA Today March:32-34.

CEDRONE, L. 1992. No time to waste. Bobbin 33 (8):42-43.

CFSA see CLOTHING FEDERATION OF SOUTH AFRICA.

CHATTERJEE, C. 1996. Recycling and reuse of textile waste. The Indian Textile Journal 106(8):116118.

CLOTHING FEDERATION OF SOUTH AFRICA. 1997. The South African clothing industry executive handbook. Bedfordview.

COHEN, J. 1988. Statistical power analysis for the behavorial sciences. $2^{\text {nd }}$ ed. Hillsdale. Lawrence Erlbaum.

CONCISE OXFORD DICTIONARY. 1990. ALLEN, RE. Oxford Dictionary. $8^{\text {th }}$ ed. Oxford. Clarendon.

DAHMEN, A. 1993. Hoechst fibers: Outlook and developments. Textile Month January:35-39.

DE WET, JJ, MONTEITH, JLdK, STEYN, HS \& VENTER, PA. 1981. Navorsingsmetodes in die opvoedkunde: 'n Inleiding tot empiriese navorsing. Durban. Butterworth.

DIESENHOUSE, S. 1994 Polyester becomes environmentally correct. New York Times 9 Feb:20.
DILLMAN, DA. 1978. Mail and telephone surveys: The total design method. New York. Wiley.

DOCKERY, A \& KALOGERIDIS, C. 1993. U.S. Textiles protecting tomorrow's community. American Textile International September:32-49.

DOMINA, T \& KOCH, K. 1997. The textile waste lifecycle. Clothing and Textiles Research Journal 15 (2):96-102.

DREF2: Spinning wealth from waste. 1995. The Indian Textile Journal 105(10):102-105.

FERRELL, OC, HARTLINE, MD \& LUCAS, GH. 2002. Marketing strategy. $2^{\text {nd }}$ ed. Mason, Ohio. SouthWestern.

FOLK, M. 1994. Making use of scraps: Burlington finds way to turn yarn into jeans. Greensboro News and Record October:4.

GHOSH, S \& HORROCKS, AR. 1995. Recycling: Polypropylene tapes for carpet backing and geotextiles. The Indian Textile Journal 105(5):26-34.

GRASSO, MM. 1995. Recycled textile fibres: The challenge for the twenty-first century. Textile Chemist \& Colorist 27(5):16-20.

HARTMAN GROUP. 1994. A primer on environmental issues. Hosiery News August:26-29.

HEELEY, J. 1995. Ecotextile '95: Wealth from waste in textiles. Textile Magazine 2:23-24.

KALOGERIDIS, C. 1990. Dont't waste your waste: It's like burning dollars. Textile World 140(12):68-69.

LARNEY, M. 1998. Hersiklering van soliede afval in die tekstiel- en klerebedryf in Suid-Afrika. MSc dissertation. North-West University, Potchefstroom.

LARNEY, M, VAN AARDT, AM \& GRASSO, MM. 1996. Recycling of textiles: Green panacea or red herring? Journal of Dietetics and Home Economics 24(2):83-89.

MONOMER AND POLYMER PRODUCTION: DESTIGMATISING THE POOR IMAGE OF PLASTICS. 1992. Technology SA March:23-24.

MOUTON, J \& MARAIS, HC. 1989. Metodologie van die geesteswetenskappe: Basiese begrippe. Pretoria. Raad vir Geesteswetenskaplike Navorsing.

MURPHY, KR \& DAVIDSHOFER, CO. 1994. Psychological testing: Principles and applications. $3^{\text {rd }}$ ed. Englewood Cliffs, NJ. Prentice-Hall.

RUDIE, R. 1994. How green is the future? Bobbin 35(6):16-20.

TEXTILE WASTE PROCESSING LINES. 1994. TeXtile Month December:13.

WARD, D. 1995. There's nothing new about recycling. Textile Month June:30-31.

WIRTHS, W. 1988. H. Schirp \& Co.: recycling of hard waste. Textile World 138(4):72-74. 